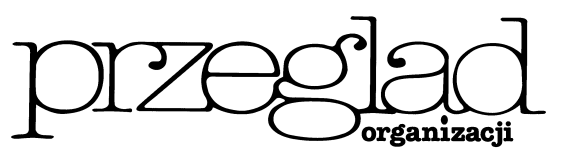

\title{
Źródła rynkowej przewagi konkurencyjnej przedsiębiorstwa
}

https://doi.org/10.33141/po.2005.10.02

Przegląd Organizacji, Nr 10 (789), 2005, ss. 13-15 www.przegladorganizacji.pl

\section{Zdzisław Pierścionek}

Towarzystwo Naukowe Organizacji i Kierownictwa (TNOiK)

Przewaga konkurencyjna przedsiębiorstwa na danym rynku w danym okresie jest rezultatem wyższej relatywnej wartości oferty tego przedsiębiorstwa w porównaniu z ofertami konkurentów. Przewaga ta dotyczy pewnej określonej grupy odbiorców, tj. tych, którzy postrzegają wartość danej oferty z punktu widzenia swoich własnych preferencji jako większą i skutecznie promowaną, a więc jako konkurencyjną na tle innych ofert. Większa wartość oferty może wynikać, jak wiadomo, z wyższej postrzeganej jakości, nowości, różnorodności, wyróżnienia się - przy porównywalnej cenie, czy z lepszego serwisu, kanałów dystrybucji, krótszego czasu realizacji zamówienia i obsługi, większej marki i renomy. Źródła rynkowej przewagi konkurencyjnej przedsiębiorstwa można zaliczyć do 3 poziomów ${ }^{1)}$ :

- bezpośrednie źródła rynkowej przewagi konkurencyjnej,

- bazowe źródła konkurencyjności przedsiębiorstwa,

- zewnętrzne źródła konkurencyjności przedsiębiorstwa.

Bezpośrednie źródła rynkowej przewagi konkurencyjnej przedsiębiorstwa to te procesy i systemy, które bezpośrednio określaja możliwości rynkowej przewagi konkurencyjnej przedsiębiorstwa. Należą tu ze sfery realnej: technologia, wielkość i lokalizacja przedsiębiorstwa, ze sfery regulacji: jakości systemu zarzadzania, a w tym poziom umiejętności marketingowych oraz zarządzania strategicznego. Te bezpośrednie źródła są z kolei uwarunkowane przez źródła, które określić można jako bazowe, stanowiące strukturalną, trwałą podstawę konkurencyjności przedsiębiorstwa.

Wiodącymi koncepcjami bazowych źródeł konkurencyjności przedsiębiorstwa są koncepcje kluczowych kompetencji (Hamel-Prahalad), wyróżniających firmę zdolności (Kay) oraz organizacji uczącej się i bazującej na wiedzy

Między koncepcjami Hamela i Prahalada oraz Kaya, a także organizacji uczącej się i bazującej na wiedzy występują istotne różnice. Dotyczą one sposobu określania źródeł przewagi konkurencyjnej, jak i całej koncepcji konkurowania.

Koncepcja konkurencyjności opracowana przez Hamela i Prahalada zakłada, że podstawowym źródłem przewagi konkurencyjnej przedsiębiorstwa sa zdolności do kreowania innowacji wynikające z posiadania przez dane przedsiębiorstwo kluczowych kompetencji. Kluczowe kompetencje stanowia zestaw umiejętności, wiedzy i technologii, charakteryzuja się kluczowym wkładem w najważniejsze wartości dla odbiorcy, unikatowością oraz możliwością wprowadzenia gamy nowych produktów. Kluczowe kompetencje można i należy tworzyć, co wymaga posiadania wizji rozwoju rynku, aktywnego uczestnictwa w transformacji branży oraz w procesie konkurencji o nowe zasoby i umiejętności².

Koncepcja konkurencyjności przedsiębiorstwa opracowana przez Johna Kaya zakłada, że źródłem przewagi konkurencyjnej przedsiębiorstwa są wyróżniające firmę zdolności. Podstawą konkurencyjności przedsiębiorstwa jest wykrycie wyróżniających daną firmę zdolności, które mogą stanowić: architektura, reputacja, innowacje oraz zasoby strategiczne. J. Kay zakłada, że wyróżniające zdolności posiada każde przedsiębiorstwo utrzymujące się na rynku. Drugim podstawowym warunkiem osiagnięcia konkurencyjności przedsiębiorstwa jest właściwe wybranie rynków, tj. dostosowanych do posiadanych wyróżniających daną firmę zdolności. Wyróżniających firmę zdolności nie da się świadomie tworzyćc ${ }^{3)}$. Według J. Kaya atrakcyjność inwestycyjna rynków nie ma zasadniczego znaczenia w procesie ich wyboru, natomiast w koncepcji Hamela i Prahalada atrakcyjność rynków odgrywa bardzo istotna rolę.

Zasadniczą różnica tych dwóch koncepcji osiagania i utrzymania konkurencyjności jest ocena możliwości świadomego tworzenia źródeł konkurencyjności w postaci kluczowych kompetencji (Hamel-Prahalad), czy wyróżniających firmę zdolności (Kay). Ci pierwsi twierdza, że jest to możliwe i konieczne, ten drugi, że nie jest to możliwe. Koncepcja Hamela i Prahalada dotyczy przyszłości, związana jest z rozwojem zasobów przedsiębiorstwa, przyszłym kształtem branży, aktywnym kształtowaniem tej przyszłości. Natomiast koncepcja Kaya dotyczy istniejących zasobów i warunków otoczenia. Hamel i Prahalad jako cel działań konkurencyjnych formułują przewodnictwo rynkowe, podczas gdy Kay mówi o trwałej pozycji na ryn$\mathrm{ku}$, niekoniecznie pierwszej.

Bazowe źródła konkurencyjności są różnie określone w koncepcjach Hamela i Prahalada oraz Kaya. W pierwszym przypadku sa to kluczowe kompetencje, a w drugim wyróżniające firmę zdolności. Istota pojęć kluczowych kompetencji oraz wyróżniających firmę zdolności jest podobna. Definiowane są one za pomoca tych samych określeń, tj. umiejętności, zdolności (możliwości), wiedzy, technologii i procesów. Inaczej natomiast są przedstawiane same źródła konkurencyjności. U Kaya sa to specyficzna architektura, innowacje, reputacja, zasoby strategiczne, umie- 
jętności rozpoznania wyróżniających zdolności i umiejętności wyboru rynków. Hamel i Prahalad jako źródła konkurencyjności przedsiębiorstwa określają integrację różnorodnych umiejętności, dobór ich struktury, przewagę wiedzy na temat przyszłości oraz w metodach tworzenia nowych kluczowych kompetencji. W obu koncepcjach podkreśla się rolę uczenia się przedsiębiorstwa w kształtowaniu kluczowych kompetencji, w procesie identyfikacji wyróżniających zdolności, a także wyboru rynków. Widzimy więc silny związek obu tych koncepcji z ideą organizacji uczącej się oraz bazujaccej na wiedzy.

Koncepcje Hamela i Prahalada były inspiracją dla wielu dalszych prac nad kluczowymi kompetencjami oraz wyróżniającymi zdolnościami. Tak więc można mówić o wielu wariantach tych koncepcji. Ich autorzy w określeniu źródeł przewagi konkurencyjnej przedsiębiorstwa posługują się głównie takimi pojęciami, jak: kompetencje (competencies), zdolności, możliwości (capabilities), umiejętności (skills), a także wiedza (knowledge), kwalifikacje oraz technologie. Różne wersje określeń źródeł przewagi konkurencyjnej przedsiębiorstwa posługują się różnymi pojęciami. Tak więc Hamel i Prahalad określają te źródła jako kluczowe kompetencje przedsiębiorstw, J. Kay jako wyróżniające firmę zdolności, G. Stalk, Ph. Evans, L. Shulman jako kompleksowe możliwości (capabilities). Kluczowe znaczenie dla określenia źródeł bazowych przewagi konkurencyjnej przedsiębiorstwa mają cztery terminy, tj. kompetencje, zdolności (możliwości), umiejętności oraz uczenie się i wiedza. Różnice mię- dzy trzema pierwszymi pojęciami trudno jest jednoznacznie określić, dotyczy to szczególnie kompetencji oraz zdolności. Niektórzy autorzy traktują jako synonimy kompetencje oraz zdolności lub definiują kompetencje przez możliwości ${ }^{4}$. Niektórzy autorzy używają zamiennie pojęć zdolności oraz umiejętności, a definiują kompetencje stosując termin umiejętności. Hamel i Prahalad definiuja kluczowe kompetencje jako zintegrowany zestaw różnorodnych umiejętności i technologii ${ }^{5}$. R. Kanter kluczowe kompetencje definiuje jako wyróżniające zdolności, procesy i zaso$b y^{6}$. Kompetencje określane są jako możliwości robienia czegoś cennego dla klientów.

Kluczowe kompetencje przedsiębiorstwa traktuje się, z punktu widzenia organizacji uczącej się, jako złożone związki umiejętności zbiorowego uczenia się, które sa wykorzystywane w procesach organizacyjnych ${ }^{7)}$. Są więc tu podejśsia oparte na teorii organizacji uczącej się. Jeszcze inne określenie kluczowych kompetencji posługuje się pojęciem wiązki zasobów, procesów i zdolności leżących u podstaw przewagi konkurencyjnej ${ }^{8)}$. Jak można sądzić uproszczone relacje między czterema kluczowymi pojęciami można określić tak, jak to przedstawiono na rysunku. Punktem wyjścia do określenia źródeł przewagi konkurencyjnej przedsiębiorstwa jest posiadana przez poszczególnych pracowników, zespoły (formalne i nieformalne) oraz organizację jako całość wiedza oraz istniejąca technologia (procesy). Wiedza ta, uwarunkowana przez kwalifikacje, doświadczenie, intelekt, procesy uczenia się organizacji, obejmuje wiedzę techniczną

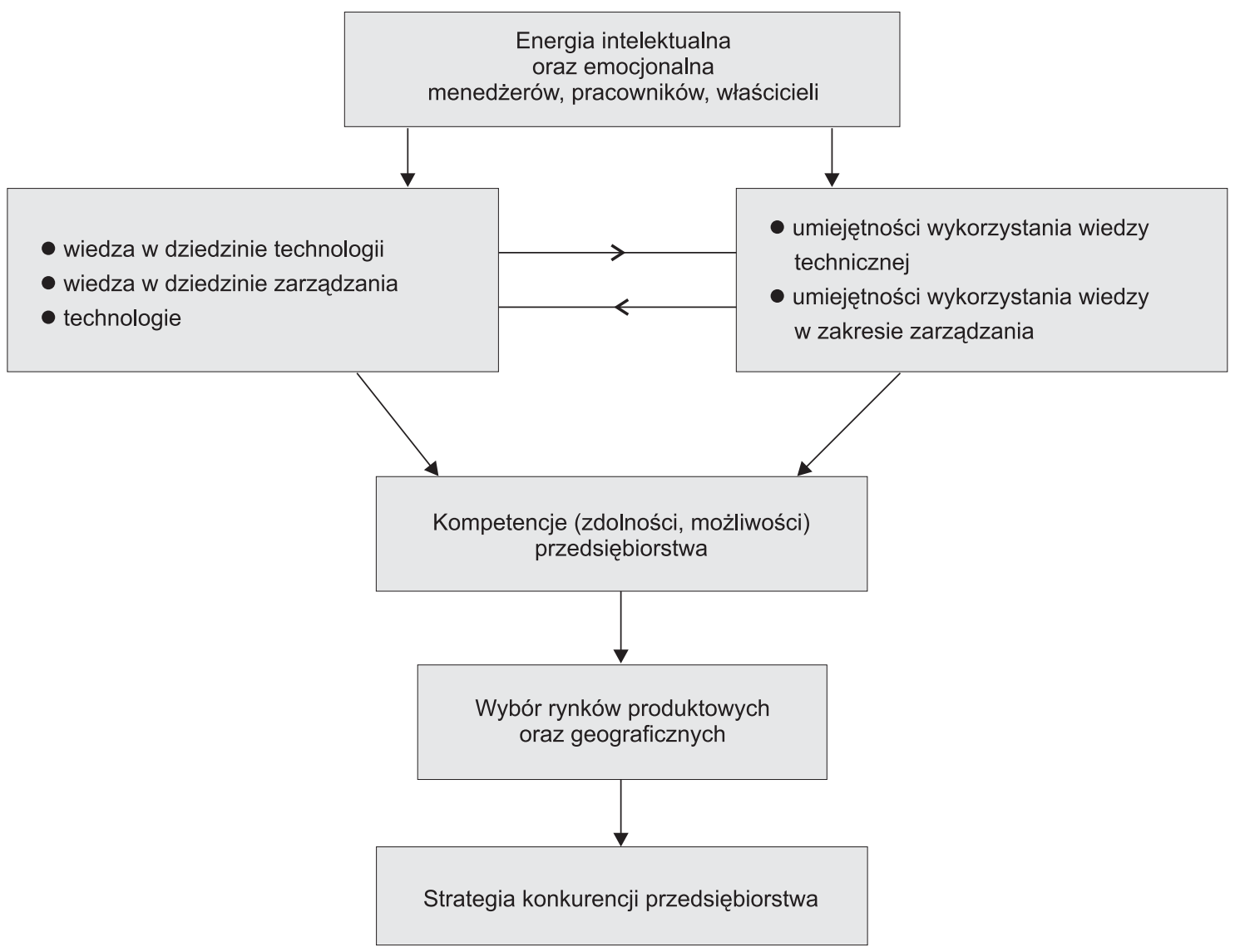

Rys. Powiązania wiedzy, umiejętności oraz zdolności firmy 
oraz wiedzę w dziedzinie zarządzania (w tym marketingu, finansów, logistyki, kadr, innowacji, zarządzania strategicznego). Wiedza techniczna oraz ta w dziedzinie zarządzania stanowią potencjał, który może przekształcić się w konkretne zdolności firmy. To właśnie umiejętności pozwalają na wykorzystanie wiedzy skumulowanej w przedsiębiorstwie. Umiejętności wykorzystania wiedzy skumulowanej w przedsiębiorstwie zależą od zastosowanych systemów organizacji zarządzania, doboru ludzi, systemów bodźców (materialnych i niematerialnych). Można stwierdzić, że umiejętności zastosowania wiedzy technicznej oraz tej w dziedzinie zarządzania stanowią określony specyficzny rodzaj wiedzy, tj. dotyczącej sposobów zastosowania wiedzy, a więc umiejętność budowy struktur organizacyjnych, systemu bodźców kształtujących odpowiednie relacje między ludźmi. Ta specyficzna wiedza $\mathrm{w}$ istotnym stopniu wynika $\mathrm{z}$ doświadczenia, a więc procesu uczenia się organizacji. Wiedza techniczna, wiedza w dziedzinie zarządzania, umiejętności ich wykorzystania (struktury, systemy) wraz z energią intelektualną oraz emocjonalną ludzi mających decydujący głos w przedsiębiorstwie, ich ambicje, cele, pragnienia i dążenia, tworzą zdolności (możliwości) tego przedsiębiorstwa. Zdolności te, to głównie zdolności do tworzenia innowacji oryginalnych, bądź zdolności do twórczego naśladownictwa, zdolności do dostrzeżenia i wykorzystania okazji, zdolności do przywództwa kosztowego, jakościowego, w dziedzinie promocji, serwisu, dystrybucji, przewagi czasowej. Specyficznym typem zdolności są zdolności do uczenia się organizacji. Te zdolności warunkują inne wymienione zdolności. Zdolności do uczenia się organizacji są uwarunkowane także wiedzą (m.in. na temat znaczenia intensywnego uczenia się organizacji w kształtowaniu zdolności firmy, rodzajów potrzebnej wiedzy) oraz umiejętnościami jej wykorzystania (wiedza i doświadczenie dotyczące struktur i systemów zapewniających efektywne uczenie się) i energią intelektualną i emocjonalną, uwarunkowanych z kolei przez otoczenie, w którym powstało i rozwijało się dane przedsiębiorstwo.

Aktualna wiedza o kluczowych czynnikach warunkujących skuteczność systemu zarządzania podkreśla znaczenie informacji oraz nowoczesnych systemów i technologii informacyjnych w kształtowaniu wiedzy i umiejętności, a więc kompetencji firmy. Decydująca rolę w kształtowaniu wiedzy i umiejętności firmy pełni proces uczenia się. Tak więc, im bardziej dane przedsiębiorstwo zbliża się do struktury organizacji uczącej się, tym większe ma szanse na tworzenie i wykorzystanie źródeł konkurencyjności przedsiębiorstwa.

Uniwersalną, sięgającą do najgłębszych źródeł konkurencyjności przedsiębiorstwa jest koncepcja organizacji uczącej się bazującej na wiedzy. Koncepcja ta opiera się na następujących podstawowych założeniach:

- wiedza organizacji i umiejętności jej wykorzystania na konkurencyjnym poziomie stanowią kluczowe źródło przewagi konkurencyjnej;

- uczenie się wewnątrz organizacji ma decydujące znaczenie dla poziomu wiedzy (obok uczenia się poza organizacją, a więc w rodzinie, szkołach, uczelniach, stowarzyszeniach, na kursach, szkoleniach itd.);
- skuteczne uczenie się organizacji wymaga gruntownej przebudowy jej struktury i systemów.

Różne koncepcje konkurencyjności przedsiębiorstwa jako warunek niezbędny ich realizacji formułuja zasadniczą przebudowę struktury przedsiębiorstwa. Przewaga konkurencyjna $\mathrm{w}$ rezultacie uczenia się wewnątrz organizacji zostanie osiągnięta pod warunkiem przekształcania przedsiębiorstwa w organizację uczącą się, bazującą na wiedzy.

W praktyce każde przedsiębiorstwo jest w pewnym stopniu organizacją uczącą się, opartą na wiedzy. Jak można sądzić przedsiębiorstwo przyszłości, które będzie sobie radzić z konkurencją w przyszłych warunkach, to takie, które istotnie przebuduje swoje struktury i umiejętności w dostosowaniu do nowych warunków otoczenia. Przebudowa organizacji powinna polegać na wprowadzeniu struktur i systemów w organizacji, które zapewnią systematyczny dopływ potrzebnej wiedzy z otoczenia organizacji, permamentne uczenie się wewnątrz organizacji obejmujące wszystkich jej członków, odpowiednie gromadzenie i magazynowanie wiedzy, ciągłe dzielenie się wiedzą wśród pracowników oraz odpowiednie wykorzystanie wiedzy. W opisie organizacji uczacej się, bazującej na wiedzy można i należy stosować teorię kluczowych kompetencji (czy wyróżniających firmę zdolności). Można definiować i analizować m.in. kluczowe kompetencje w zakresie uczenia się, dzielenia się i wykorzystania wiedzy w organizacji.

Nowe koncepcje źródeł przewagi konkurencyjnej przedsiębiorstwa (i szerzej koncepcje konkurencyjności) stanowią, jak można sądzić, istotny postęp w naukach o przedsiębiorstwie. Stanowią istotny nowy dorobek zarządzania strategicznego, który wejdzie do dorobku m.in. teorii konkurencji oraz teorii firmy. Problemy, które te teorie formułuja, i co do których proponują rozwiązania, nie są tylko ich opisem przy zastosowaniu innych nowych pojęć, jak: umiejętności, wiedza, zdolności, możliwości, kompetencje, kluczowe kompetencje, wyróżniające firmę zdolności. Teorie te stawiają nowe pytania (o bazowe źródła przewagi konkurencyjnej) oraz proponują nowe rozwiązania.

prof. zw. dr hab. Zdzistaw Pierścionek Szkoła Główna Handlowa

\section{PRZYPISY}

1) Por. Z. PIERŚCIONEK i in., Czynniki sukcesu polskich przedsiębiorstw na rynku UE, Ministerstwo Nauki i Informatyzacji 2005.

2) Por. G. HAMEL, C. PRAHALAD, The Core Competences of the Corporation, „Harvard Business Review”, June 1990.

3) J. KAY, Podstawy sukcesu firmy, PWE, Warszawa 1996, s. 185.

4) Zob. na przykład M. BRATNICKI, Kompetencje przedsiębiorstwa, Placet, Warszawa 2000, s. 7.

5) Por. G. HAMEL, C. PRAHALAD, Przewaga konkurencyjna jutra, Business Press, Warszawa 1999, s. 170.

6) R. KANTER, On the Frontiers of Management, Harvard Busines School Press, Boston 1997, s. 29.

7) M. BRATNICKI, Kompetencje przedsiębiorstwa, Placet, Warszawa 2000, s. 23.

8) J. THOMPSON, B. RICHARDSON, Strategic and Competitive Sources, „Management Decision” 2/1996. 